\title{
HOME VISIT: CARE TECHNOLOGY USED BY NURSES TO ADVOCATE FOR CHILD'S HEALTH ${ }^{1}$
}

\author{
Raquel Dully Andrade², Jaqueline Silva Santos ${ }^{3}$, Maria Ambrosina Cardoso Maia ${ }^{4}$, Marta Angélica Iossi \\ Silva ${ }^{5}$, Maria de La Ó Ramallo Veríssimo ${ }^{6}$, Débora Falleiros de Mello ${ }^{7}$
}

\footnotetext{
${ }^{1}$ Extracted from the Dissertation - Child's health advocacy: nursing care and right to health in primary health care. Programa de Pós-Graduação em Enfermagem em Saúde Pública, Escola de Enfermagem de Ribeirão Preto (EERP), Universidade de São Paulo (USP), in 2012.

2 Ph.D. in Sciences. Professor, Nursing Program, Universidade do Estado de Minas Gerais (UEMG), Passos, Minas Gerais, Brazil. Email: radully@gmail.com

${ }^{3}$ Doctoral student, Public Health Nursing Graduate Program, EERP/USP, Ribeirão Preto, São Paulo, Brazil. Email: jaquelinessantos@usp.br

${ }^{4}$ Ph.D. in Nursing. Professor, Nursing Program, UEMG, Passos, Minas Gerais, Brazil. Email: ambrosinacardoso@yahoo.com.br

${ }^{5}$ Ph.D. in Nursing. Associate Professor, Departamento de Enfermagem Materno-Infantil e Saúde Pública, EERP/USP, Ribeirão Preto, São Paulo, Brazil. Email: maiossi@eerp.usp.br

${ }^{6}$ Ph.D. in Nursing. Associate Professor, Departamento de Enfermagem Materno-Infantil e Psiquiátrica, Escola de Enfermagem USP, São Paulo, Brazil. E-mail: mdlorver@usp.br

7 Ph.D. in Nursing. Associate Professor. Departamento de Enfermagem Materno-Infantil e Saúde Pública, EERP/USP, Ribeirão Preto, São Paulo, Brazil. Email: defmello@eerp.usp.br
}

\begin{abstract}
This study aimed to identify elements of care designed to protect children during home visits, from narratives of nurses, from the perspective of care and advocacy for the right to health of children. This is an exploratory study using qualitative thematic analysis, based on conceptual aspects of care and the right to health, from interviews with 14 nurses working in the Family Health Strategy. The narratives about the actions of nurses in home visits show protective measures of child health, organized into themes: observation and intervention for child care at home; arrest of situations of rights violation; child vulnerabilities with parental users of alcohol and other drugs. The home visit proved to be a fundamental tool for clinical practice in primary health care, constituting a privileged space for the nursing care of the child, and a family context for child health advocacy.
\end{abstract}

DESCRIPTORS: Child health. Home visit. Pediatric nursing. Community health nursing. Right to health.

\section{VISITA DOMICILIÁRIA: TECNOLOGIA DE CUIDADO UTILIZADA PELO ENFERMEIRO NA DEFESA DA SAÚDE DA CRIANÇA}

RESUMO: Este estudo objetivou identificar elementos do cuidado em favor da infância na visita domiciliária, a partir de narrativas de enfermeiros, na perspectiva do cuidado e da defesa do direito à saúde da criança. Trata-se de estudo exploratório com análise qualitativa temática dos dados, fundamentado em aspectos conceituais do cuidado e do direito à saúde, a partir de entrevistas com 14 enfermeiros atuantes na Estratégia Saúde da Família. As narrativas sobre as ações do enfermeiro na visita domiciliária evidenciaram medidas de proteção à saúde infantil, organizadas nos temas: Observação e intervenção para o cuidado da criança em casa; Apreensão de situações de violação de direitos; Vulnerabilidades na infância com pais usuários de álcool e outras drogas. A visita domiciliária mostrou-se como ferramenta fundamental para a prática clínica em atenção primária à saúde, constituindo espaço privilegiado para a atenção da enfermagem à criança e ao contexto familiar, na advocacia pela saúde infantil.

DESCRITORES: Saúde da criança. Visita domiciliar. Enfermagem pediátrica. Enfermagem em saúde comunitária. Direito à saúde.

\section{VISITA DOMICILIÁRIA: TECNOLOGÍA DEL CUIDADO UTILIZADA POR ENFERMEROS EN LA DEFENSA DE LA SALUD DEL NIÑO}

RESUMEN: Este estudio tuvo como objetivo identificar elementos de cuidado favorables a la infancia en la visita domiciliaria, desde las narrativas de enfermeros, en la perspectiva de la atención y de la defensa del derecho a la salud de los niños. Estudio exploratorio con análisis temático cualitativo, basado en aspectos conceptuales del cuidado y derecho a la salud, a través de entrevistas con 14 enfermeros que trabajan en la Estrategia de Salud Familiar. Narrativas muestran las medidas de protección de la salud infantil, organizada por temas: Observación e intervención para el cuidado del niño en el hogar; Incautación de situaciones de violación de derechos; La vulnerabilidad en la infancia con padres usuarios de alcohol y otras drogas. La visita domiciliaria es una herramienta esencial de la práctica clínica en la atención primaria de salud, que constituye un espacio privilegiado para los cuidados de enfermería al niño y al contexto familiar en la defensa de la salud infantil.

DESCRIPTORES: Salud del niño. Visita domiciliaria. Enfermería pediátrica. Enfermería en salud comunitaria. Derecho a la salud. 


\section{INTRODUCTION}

Children's health, within primary health care, aims to ensure the follow-up and monitoring of child growth and development in a comprehensive and longitudinal manner, ${ }^{1}$ which is critical to assist with the essential needs of children and for the analysis of vulnerable situations for them and for the family, when faced with adverse conditions for their development. ${ }^{2}$

It is important that health professionals recognize the needs of individuals and provide resources so that these needs can be addressed, especially those working in the Family Health Strategy (FHS), which is understood as a proposal for the reorientation of the care model, "in order to intervene effectively and offer quality in care delivery to change health conditions" ${ }^{3: 203}$

Whereas the child's interaction process with the environment is central to his/her health and development, family care and household conditions are elements that should be the focus of attention of health professionals. In this sense, the home visit (HV) can contribute in a valuable way to health promotion, disease prevention, treatment, and health recovery.

The health care of the child at home, and the $\mathrm{HV}$, have been considered as relevant issues and themes of interest in many studies. ${ }^{4-7}$ In child health, the HV is identified as a tool aimed at the promotion of health to achieve a healthy growth and development, ${ }^{4}$ to assess mother-child interaction and the care of children, ${ }^{5}$ and to identify vulnerable situations, ${ }^{6}$ as well as to contribute to the improvement of women's journeys as mothers and to support children and families?

However, some aspects of the HV related to the advocacy for the right to health of children are hardly widespread, particularly in the area of nursing. ${ }^{8-9}$ Thus, this study aimed to identify elements of care on behalf of children, during the performance of the HV, by using narratives of nurses from the perspective of care and children's health advocacy.

\section{METHODS}

This was an exploratory study with qualitative data analysis, based on the concept of care, understood as an interaction between subjects, aimed at health care in a dialogic basis, ${ }^{10}$ and using the perspective of the right to health, envisioned as a fundamental right which re- quires concrete initiatives from the State for its achievment. ${ }^{11}$

The survey was conducted in the city of Passos, State of Minas Gerais (MG), Brazil, with nurses working in FHS units. The municipality has 17 family health teams, each one with a nurse, and covers $73 \%$ of the inhabitants. The invitation for the study was made to all nurses working in FHS units. One nurse refused to participate and two were on sick leave, resulting in a total of 14 nurses included in the study.

In a brief description of the characteristics of the study participants, we highlight that 12 were female, eight were between 30-34 years, six had graduated as nurses, four to six years before the interviews and seven reported work experience in the FHS between four to six years.

Data collection was conducted in 2012, through recorded, semi-structured interviews, providing a stimulus for the free form of speech, ${ }^{12}$ lasting about 40-80 minutes, allowing nurses to report child and family care issues, with emphasis on child health advocacy in the context of the HV. The interviews were conducted in the FHS units, and the following guiding question initiated the data collection: "Can you tell me about a situation in which you experienced the need for some sort of child health advocacy?"

All the material was typed and organized into individual files. The analysis aimed to identify and discuss operational meanings in the nurses' narratives, about situations and actions related to the practice during $\mathrm{HV}$, from the perspective of care and advocacy for the right to health. ${ }^{10-11}$ Therefore, the following steps of thematic content analysis were followed ${ }^{12}$ : a) preliminary reading of the material with the objective of mapping the meanings attributed by the subjects; b) interpretation of the contents across the guiding directions extracted from the reports; c) elaboration of a synthetic interpretation and organization of meanings into thematic units. In the description of the results, participants were referred to as E1, E2 through E14.

The investigation was authorized by the Municipal Board of Health and approved by the Research Ethics Committee (protocol 25/2011 of the Fundação de Ensino Superior de Passos (FESP), and followed the recommendations for research on human subjects, with explicit acceptance by participants through their signature on the Terms of Free and Informed Consent. 


\section{RESULTS}

The results were grouped into thematic units that represent aspects related to the practice of nurses in the context of a HV, namely: observation and intervention for pediatric home care; identification of rights violation cases; vulnerabilities in childhood with parents that present with alcohol/ drug addiction.

\section{Observation and intervention for pediatric home care}

According to the nurses' perception, the HV constitutes a favorable moment for health monitoring, as it allows observation and assessment not only of the children's conditions, but also of their life situations, identifying vulnerabilities, conducting preventive counseling, and requesting the performance of other professionals and services, as well as providing communication between staff.

When the family does not use regularly the health services, it becomes even more important for professionals to conduct health monitoring and protection of children's health.

Those mothers who are rebels, who do not bring the kid for weights, I will, I'm going after them, I'll talk, to know why [the mother does not bring the child to the health service]. You, just by seeing the house, you can see that the situation is very poor, these cases where mothers don't bring the child here need to be analyzed (E6).

However, the recognition of the child's living conditions, made possible by the HV mainly for those families who rarely attend the service, generates additional demand for other resources that are needed to ensure children's rights.

The lady is 42 years old and she already has ten children. Her children are unattended, they are only seen when we perform the home visits. The doctor has to go there to care for those children; they do not come here. The principle of the school phoned us, wondering what we can do. I feel like I have my hands tied. I asked for help from the NASF [Support Center for Health] and we are working together in favor of it, but it depends largely on the mother. I think the prosecutor will have to intervene, because the mother, even if she wants to, there's no way... She has this baby less than two months old... she did not bring the baby to perform the heel prick test, and she did not bring him to get the vaccine, nothing at all. And it's one after another, a sequence. So she did not leave the house. Our team has to go after her. She is in need of everything, food, it is a social issue, an economic issue, everything you imagine, and it is a serious case (E10).

The professional internalizes the institutionalized HV, referring to autonomy in being closer by working in the household. The presence of nurses in the enrollment area is also a facilitating factor to meet and establish proximity to the families.

I have this freedom to go to the house. So I think it's very good, because the more we stay in the area, the more you know it and the more freedom you have (E3).

The HV is also seen as a good intervention from the service to a predictable care demand: the need related to care and support for breastfeeding mothers. This action is developed in addition to others, such as prenatal care, aimed at a longitudinal, comprehensive care.

We have approached breastfeeding in the pregnancy education course. And they have been excited around breastfeeding. And we left the door open, because the difficulty will come when the baby comes, when the nipples get sore and the breasts are all swollen. And there will be a need for professional support, and if the professional is not there at the time, that's where the breastfeeding will be interrupted. So, we have to be prepared to assist them by the time this happens, to perform home visits and offer help (E8).

The home visit during the postpartum period is an important opportunity to care for the child and woman, with extension to the family. We highlight the support to the mother-woman considering the postpartum period as a time of emotional sensitivity and family complexity.

I had a case of a mother who was unable to breastfeed at all. She was nervous and speaking about getting divorced. I got there, I sat down, and I helped her to breastfeed the child. It took a while, but she managed it ... I was talking to her, saying, hey it's a new thing, it's family, you have to be patient. 'It is a time of great sensitivity, both for women as well as for the family (E1).

There are situations where it is difficult for professionals to accept maternal decisions, such as when the mother refuses to breastfeed, despite not being able to afford to feed her children adequately. This requires professionals who perform the HV in a more sensitive manner, without judgment, as well as a better understanding of the complexity and uniqueness that surrounds each mother, child and family, in addition to actions for the protection of children's rights.

I was visiting a teenage mother [...] I went there, the milk came in, and the breast was engorged. The 
house, so dirty, so poor, she did not know who the father was. I went there, her breast was not in [a hygienic] condition, I said, 'Let's wash this breast first'. She said: "There's no way, I will not breastfeed!' I said: 'Why? Look how much milk you have!'. She said, 'But I have no nipple...' Then I said 'me too, and I breastfed. I'll help you'. 'No, I will not breastfeed", she insisted. And she meant it: she did not breastfeed.... despite the difficult conditions, poverty... they had nothing! But then she obtained some formula, and she entered a social program. This might have happened a year ago... until the doctor was very angry with her, but she continued: 'No, I do not have a good nipple, it hurts too much, I do not like it. There is no way!' (E7).

The HV offers a time for observation and assessment of cultural and current issues, impacted by social reality. It allows for the identification of trends of increased vulnerability regarding the quality of food during childhood. Professionals claim that currently mothers and fathers devote less time to their homes. They also point out that the media influences eating, imposing the consumption of fast food in detriment to natural and healthy food.

We observe inside the houses that healthy eating is something very distant. It is difficult because the influence of industry gets too strong. In case of overweight, we also try to see what is happening at home. If the mother is using lots of industrialized products we advise her to stop eating them. If you see that you are not getting a result, the dietician will also go (E9).

We have seen, through visits, that teenagers do not care about their food or childhood eating habits. At a certain age the child's food is different from the family's eating, and the teenagers are discouraged to prepare it. There is one child that is losing weight because the mother is too lazy to go to the kitchen. So she is feeding the child only with milk, which is easy, she fills the baby bottle with milk and puts it in the baby's mouth, the kid is all by himself. When we arrived at the household, that is something we come across. Not to mention the trouble with feeding the baby, the long time it takes. Teens do not have the patience (E8).

To ensure the child's right, it is essential to characterize the causes of family difficulties in providing proper care and design consistent actions, which is favored by the HV.

The feeding of the child is unsatisfactory, either due to the lack of conditions or lack of mother's will. We can evaluate it better during the visit. When it is the case of lack of will, we try to advise that milk alone will not be enough for good development. Now, when you see that the case is related to economic shortage, we refer the family to get support from churches, to obtain the multimixture [nutritional supplement] from the Child's Pastoral, we require these partners (E8).

\section{Identification of rights violation cases}

Nurses value the $\mathrm{HV}$, considering it a way to promote children's rights and identify vulnerabilities. Many of the vulnerabilities highlighted in our findings result from social changes and family dynamics. That vulnerability is not always accompanied by adequate measures aimed at the everyday care of the child, raising concerns for professionals.

We see that the population, in general, is undergoing a change, the mothers are working, the culture that says, "the mother stays home and the man goes to work" is changing. So I think there are many interconnected things. Sometimes, the mother does not have time to stay with the child and all of a sudden she does not give the expected education for this child, and she closes her eyes to things that might be happening. And then lots of things are going on (E12).

During the HV one can detect situations of negligence and its consequences, and also can provide adequate care to the child. For a serious childhood injury situation, the home wound dressing procedure may favor greater comfort for an already traumatic and painful situation, resulting in greater humanization of the service provided in the particular space of the child, all through the HV.

The mother left the child neglected. One day she was bathing, heated the water and then put the child in the bathtub. I do not know what the mother was doing, the girl felt into the tub... two years old she was. My assistant and I were going to that house to do the wound dressing ... we cried while doing it. These mothers are very inattentive. It was a family that does not care much about the children... they only stay on the street, left aside (E11).

There has been a practice of using the HV to investigate cases of possible mistreatment of children. However, the nurse notices a limit with this action, since there may be concealment of harmful behavior by the family.

There is a child, one-year old, we were making home visits, also as a request of the Tutelage Council, since that mother already had three children who had already been taken from her custody. The only thing is... this child who we are monitoring, we watched over, 
the mother seems to be taking good care of. Generally, those who most often witness these things are the neighbors. When you need it, you try to get something from them (E4).

The HV has a great potential for professionals to uncover evidence of children's vulnerabilities and violation of rights, which must be confirmed. Such situations create anxiety for professionals who find themselves responsible for acting in favor of child advocacy.

We were suspicious of domestic violence, and who warned me was the health worker. The suspicion started during the visits. She was afraid because the child was very lonely. The family already has a history of mental problems, people were afraid of the uncle who lived nearby... that he'd be molesting the child. Those are complicated visits for us (E1).

The understanding that the child is too vulnerable and fragile to advocate for himself shows that expanding the comprehension of situations of rights violation experienced by children, as well as the exercise of advocacy, appear as important challenges for professionals.

\section{Vulnerabilities in childhood with parents that are users of alcohol/other drugs}

Drug addiction among parents has a negative effect on the health and quality of life of children. This situation is cited as a barrier to actions regarding child protection. The reported circumstances portray family difficulties in which drug use and other problems coexist, affecting the health and well being of the child, putting children in a vulnerable situation. In addition, the potential of partnership with this family is compromised. This framework increases the complexity of care, and the $\mathrm{HV}$ is of greatest importance.

The mother is totally lost, she is only sixteen and her partner is forty years old. The girl looks sick... she is malnourished. We are trying to advise, educate. The father is a truck driver, he is more on the road than here and when he comes here he is dizzy [drunk]. She lives in the backyard of her mother's house. We called the mother to talk. The mother said she was trying to help; only the girl does not accept help. The father drinks a lot. The girl is only losing weight (E7).

A grandmother who has a serious psychiatric disorder had the custody of that girl. The grandfather is an alcoholic. One day they called the CREAS [Specialized Reference Center for Social Assistance] to ask about the girl's mother, but she did not live in the residence. The mother had a recent suicide attempt,.
Then, as we were following up with the family, we found that the mother is a crack addict. So we face very complex situations (E2).

Thus, the nurse is confronted with cases in which the family is not only incapable of providing security to the child, but it is also a high-risk source of the child integrity. In these situations, child advocacy demands action from other sectors, such as justice and social work, with interventions that are outside the scope of exclusive health action.

She had the baby and she was a drug and alcohol user, so was the partner. We saw that there was no possibility. They had no relatives. Our alternative was to transfer the case to social services... at the time we had no CRAS [Social Assistance Reference Center], no CREAS, and no NASF [Support Center for Health]. We sought the social worker of the justice forum. She managed to make arrangements, and it turned out that the children had to be taken from the mother, because of the risk, very high risk, there was no possibility. I think about our work here; we have to be very careful in these matters, because it involves many factors. Users are linked to drug dealers, but at the same time, we have to try to preserve the integrity of the children (E9).

The consequences of drug addition were identified in detriment to the quality of life of the children, and contributed to exposure of the child to vulnerabilities that are difficult to address.

We have this little boy of five years, the mother is using crack. When the baby was born she gave him to a woman here in the area. Poor thing, he left one problem and entered another. She has a boyfriend who messes with drugs. The boy is so hopeless, has no limits, does what he wants, and it's all jumbled. We enrolled him in consultations and gave him a reference to the neurologist, he is monitored by a pediatrician specializing in hyperactive kids, he takes medicine. But it's his environment, you see that the boy will get lost; he is growing up in this context. It is very difficult (E13).

The girl's mother drinks. She is very polite. Last week, she said she would commit suicide, she was not holding up. It was complicated. I spoke to her, 'sit down, let's talk. You cannot do this, you have to take care of your daughter, and your daughter needs you. 'And the mother likes her, she speaks like: 'this girl is everything to me.' It is a case, as well, super complicated, because the whole family has problems (E3).

The narratives highlight complex emotional and social aspects, and evidence a child in the context of fragility and complete dependence on adult care and protection. The use of alcohol and other illicit drugs is a serious aggravating aspect in the violation of children's rights. 


\section{DISCUSSION}

The study findings emphasize the need to strengthen health surveillance, with improvement in the identification of the vulnerabilities and the mechanisms that allow the development of integrated actions and, thereby, increase the advocacy for children's health and guarantee their fundamental rights, in particular the right to health. Still, the $\mathrm{HV}$, as perceived by nurses, reasserts itself as a differentiator in working with families, such as seen in the Brazilian FHS, and may represent, most of the time, a peculiar bond among the child, the family and health professionals in order to detect complex vulnerable situations, as well as to trigger the necessary actions.

In Brazil, the model adopted for FHS proposes a reorientation of primary health care, based on ensuring the principles of universality, equity, integrity and participation in a context of decentralization and social control, seeking longitudinal care for individuals and families living in a specific territory. ${ }^{13}$ In the context of the FHS, the $\mathrm{HV}$ is considered as an interactional technique for family health care, offering potential activities for more human and friendly care, which allows connection, confidence building and household investigation, with analysis of the needs of the family and of each individual, ${ }^{14}$ thus effecting the achievement of health education. ${ }^{15}$

Thus, the fact that the FHS includes the $\mathrm{HV}$ as one of its daily practices also favors the possibility that the child and the family receive the required support in a place closer to them, contributing actively to respecting the right to health of children in the family context. This is a breakthrough within the FHS, in line with the precepts of the right to health.

Nurses have a strong performance in Brazil's FHS. In accordance with the principles that guide the expansion and reorganization of practices in this area, professionals can be considered agents to respect, protect and implement human rights. ${ }^{8-9,11}$

In this study, the reported interventions of nurses during $\mathrm{HV}$ were related to the postpartum period, and were focused on breastfeeding and protection of the child's quality of life. As for the breastfeeding advocacy, it became clear that multiple connections of actions can achieve positive impact, with the seminar on pregnancy education and the postpartum visit being cited as examples. Also, the participation of professionals in the prenatal follow-up proved to be a differential element in the quality of the bond that continues after birth, and that is crucial for the potential of advocating for child health.

Studies about the benefits of the HV address the experiences of nurses with young mothers, ${ }^{4}$ with the HV increasing the health of women and children, developing parental skills and contributing to assessment of the mother-child interaction. ${ }^{5}$ Another study demonstrated that mothers who received nurses for $\mathrm{HV}$ were emotionally and verbally more responsive during the first two years of their children's lives, and that the duration of breastfeeding was longer, while those mothers who did not regularly receive such visits did not show good performance. ${ }^{16}$

Some reports identified professional attitudes on breastfeeding, somewhat authoritarian, both from the nurse and the physician. The way in which health professionals advocate breastfeeding does not always achieve the expected results. The disclosure of judgment should be analyzed, since a person's choice as to whether or not to breastfeed is understood as a right for women to decide. Counseling on breastfeeding demands the recognition of the woman as a person, and an effort, must be made to understand her problems and difficulties.

The approaches of professionals on adherence to breastfeeding, if developed in a dogmatic manner, can turn women and families away from health services. Thus, if we take breastfeeding as an exclusive right of the child, it can create a harmful situation, ${ }^{17}$ as it moves the woman-mother from a holder of her own rights to a fulfiller of duty, which can generate emotional conflicts. Thus, the development of health actions could be seen as authoritative, and women could be vulnerable to restriction of freedom, discrimination, as well as other violations. ${ }^{11}$

When it comes to infant feeding, the narratives of the interviewed nurses indentified that factors such as low maternal education, the absence of the father in the household, and the habit of not having meals all together, suggested an increasing likelihood that the child would consume a poor diet. One study highlighted that low maternal education can be followed by the lack of access to healthy foods and appropriate information, as well as a poor ability to discern what is healthy, reflected in childhood, a phase when eating habits and lifestyle are consolidated. ${ }^{18}$ Another important aspect to be highlighted is the interventions designed to educate and empower parents to exercise positive parenting strategies, 
which allows the promotion of a healthy diet and physical activity. ${ }^{19}$

Deprived children in the household were reported by nurses, opposing the idea of the family as a place of protection, security and care. The use of alcohol and drugs by parents appeared as a complex and delicate situation, demanding difficult interventions and resulting in a highly negative influence for child welfare. The actions developed by nurses should be aimed at preventing substance abuse among various target audiences, ultimately becoming an advocacy action for the health and quality of life of children. In this sense, we must recognize the fact that the family can become the focus of the conflict, revealing itself as a silent space for the violation of children's rights, where violence assumes different forms (negligence, psychological, physical or sexual violence) with aggression, exploration, and/or drug addiction, potentially triggering sequelae and even death..$^{20-21}$

By committing to doing their best to uncover what is happening with the child, professionals create their own tools, such as seeking additional information from neighbors, recognizing them as important sources of information, which can be the starting point for what is often urgent action regarding protection and advocacy for the child. However, the health team needs to be careful and develop communication skills, with the ability to obtain information in a humane manner, respecting ethical principles when working with families. The approach to child abuse requires interdisciplinary and intersectional action, and the notification can move the problem identified in the health service to other spaces, establishing partnerships, an action which has proven indispensable. ${ }^{22}$

In view of nurses, the situations of parental drug addiction limit the impact of actions on behalf of children, increasing their vulnerable status. Despite the numerous difficulties, the HV can do much when it comes to necessary actions in these serious health problems. ${ }^{6}$ Our findings suggest the need for improvement of the policy guidelines that follow FHS teams and the health needs of families, such as the case of a Center for Psychosocial Support for Alcohol and Drugs (CAPSad), aiming to integrate the developed actions. ${ }^{23}$

Brazilian laws and public policies, such as the 1988 Brazilian Constitution, the Statute of Children and Adolescents, the National Policy toward the right of children to living with the family and in a community, recommend that all children and adolescents need to have a family whose bonds are protected by the state and society; whereas in the face of social vulnerability or personal and family fragility, interventional strategies should prioritize actions to strengthen or renew ties, or even stimulate their formation, combining socio-economic support for the development of new forms of interaction and access to public goods and services; recognizing the need for multidisciplinary and intersectional vision to provide answers to the complexity of those situation. ${ }^{20}$

The relationships between public health and human rights must be effective to ensure that health care will be considered as a human right, and reaffirm that the perception and the radical construction of our human community are configured as possible and necessary work in both the health and justice fields. ${ }^{11}$

It remains to be noted that the right to health as a fundamental right must be conjectured from the perspective of the full protection principle, formed from a network of specific protection with broadened rights and special guarantees, and a redefinition of the perception of the subject regarding the child, and childhood as a process of absolute priority. ${ }^{24}$

The family is a place in which the child has the right to grow with protection, affection and care, aspects that are important for different categories of professionals working with children. However, the recognition that the family approach may involve different experiences, full of representations, opinions and reactions must also be relevant. ${ }^{20}$

Parents and family members are considered primary figures for child care and advocacy; and the professionals who assist this audience need to have the conditions and knowledge related to the advocacy for children's rights, and occupy a space of proximity that allows the identification of demands, needs and/or violations, imposing a position of great responsibility for the child's well-being. ${ }^{8,11}$

It is important for nurses to focus their work on the principles of primary health care, covering the comprehensiveness and the bond with the enrolled population, conducting longitudinal follow-up, integrating the development of care, and sharing accountability between users and professionals to solve problems. ${ }^{25}$ From the analysis of the narratives of the nurses, we noted different aspects of children's rights, with approaches centered on the protection of life, right to family and community, citizenship and freedom. 


\section{CONCLUSIONS}

We identified the HV as a fundamental tool for clinical practice in primary health care, constituting an advantaged field for nursing care of the child within the family background for child health advocacy. The findings also show a practice that requires in-depth health monitoring, identification and comprehension of vulnerabilities and cooperative mechanisms for integrated actions to favor interventions in defense of children's health rights. The HV also offers time for complex care, particularly in situations involving socially constructed lifestyle, considering the particularity of the family culture and history.

These issues require professional attitudes on longitudinal care, guided by the balancing of interests, ethics and persevering attitude, which are important aspects when working with families. Thus, in professional nursing practice, the abilities of showing initiative and being protective are vital, as these involve the establishment of inter-subjective interactions. The home is a special space for pediatric nursing care with an emphasis on comprehensive care of the family, aiming at tools for knowledge construction and practice development in the context of health advocacy in primary health care.

It is noted that the highlighted situations in the nurses' narratives are complex and relevant to clinical practice in primary health care. This study presents, as a limitation, the fact of having only included the perception of nurses working in FHS units. It is important to amplify studies that investigate the vision of families and other social actors as well as those that incorporate the observation of care and the analysis of mechanisms to extend health advocacy for children in different scenarios.

\section{REFERENCES}

1. Mello DF, Furtado MCC, Fonseca LMM, Pina JC. Seguimento da saúde da criança e a longitudinalidade do cuidado. Rev Bras Enferm. 2012; 65(4):675-9.

2. Silva DI, Chiesa AM, Veríssimo MLOR, Mazza VA. Vulnerability of children in adverse situations to their development: proposed analytical matrix. Rev Esc Enferm USP. 2013; 47(6):1397-402.

3. Oliveira MAC, Silva TMR. Avaliação de necessidades em saúde: um requisito para qualificar a atenção à saúde. Rev Bras Enferm. 2012; 65(2):203-5.

4. Henderson S. Community Child Health $(\mathrm{CCH})$ nurses' experience of home visits for new mothers: a quality improvement project. Contemp Nurse. 2009; 34(1):66-76.
5. Appleton JV, Harris M, Oates J, Kelly C. Evaluating health visitor assessments of mother-infant interactions: a mixed methods study. Int J Nurs Stud. 2013; 50(1):5-15.

6. Monsen KA, Fulkerson JA, Lytton AB, Taft LL, Schwichtenberg LD, Martin KS. Comparing maternal child health problems and outcomes across public health nursing agencies. Matern Child Health J. 2010; 14(3):412-21.

7. Monsen KA, Radosevich DM, Kerr MJ, Fulkerson JA. Public health nurses tailor interventions for families at risk. Public Health Nurs. 2011; 28(2):119-28.

8. Andrade RD, Santos JS, Pina JC, Furtado MCC, Mello DF. Integrality of actions among professionals and services: a necessity for child's right to health. Esc Anna Nery. 2013; 17(4):772-80.

9. Ventura CAA, Mello DF, Andrade RD, Mendes IAC. Aliança da enfermagem com o usuário na defesa do SUS. Rev Bras Enferm. 2012; 65(6):893-8.

10. Ayres JRCM. Cuidado: trabalho e interação nas práticas de saúde. Rio de Janeiro (RJ): CEPESC/ IMS-UERJ: ABRASCO; 2009.

11. França Júnior I, Ayres JRCM. Saúde pública e direitos humanos. In: Fortes PAC, Zoboli ELCP, organizadores. Bioética e saúde pública. São Paulo (SP): Edições Loyola; 2009. p. 63-9.

12. Minayo MCS. O desafio do conhecimento: pesquisa qualitativa em saúde. $12^{\mathrm{a}}$ ed. São Paulo (SP): Hucitec; 2010.

13. Souza MG, Mandu ENT, Elias NA. Percepções de enfermeiros sobre seu trabalho na Estratégia Saúde da Família. Texto Contexto Enferm [online]. 2013 [acesso 2014 Mar 20]; 22(3):772-9. Disponível em: http:/ / www.scielo.br/scielo.php?pid=S010407072013000300025\&script=sci_arttext

14. Santos EM, Morais SHG. A visita domiciliar na Estratégia Saúde da Família: percepção de enfermeiros. Cogitare Enferm. 2011; 16(3):492-7.

15. Kebian LVA, Acioli S. Visita domiciliar: espaço de práticas de cuidado do enfermeiro e do agente comunitário de saúde. Rev Enferm UERJ. 2011; 19(3):403-9.

16. Kemp L, Harris E, McMahon C, Matthey S, Vimpani G, Anderson T, et al. Child and family outcomes of a long-term nurse home visitation programme: a randomised controlled trial. Arch Dis Child. 2011; 96(6):533-40.

17. Souza SDH, Mello DF, Ayres JRCM. O aleitamento materno na perspectiva da vulnerabilidade programática e do cuidado. Cad Saúde Pública. 2013; 29(6):1186-94.

18. Molina MCB, Lopéz PM, Faria CP, Cade NV, Zandonade E. Preditores socioeconômicos da qualidade da alimentação de crianças. Rev Saude Publica. 2010; 44(5):785-92.

19. Flores-Pena Y, Ortiz-Félix RE, Cárdenas-Villarreal VM, Ávila-Alpirez H, Alba-Alba CM, Hernández- 
Carranco RG. Maternal eating and physical activity strategies and their relation with children's nutritional status. Rev Latino-am Enfermagem. 2014; 22(2):286-92.

20. Nery MA. A convivência familiar e comunitária é direito da criança e do adolescente e uma realidade a ser repensada pela escola. Cad Cedes. 2010; 30(81):189-207.

21. Reichenheim ME, Souza ER, Moraes CL, Jorge MHM, Silva CM, Minayo MCS. Violence and injuries in Brazil: the effect, progress made, and challenges ahead. Lancet. 2011;377(9781):1962-75.

22. Luna GLM, Ferreira RC, Vieira LJES. Notificação de maus-tratos em crianças e adolescentes por profissionais da equipe saúde da família. Cienc Saude Colet. 2010; 15(2):481-91.

23. Ventura CAA, Araújo AS, Moll MF. Dimensões organizacionais de um Centro de Atenção Psicossocial para dependentes químicos. Acta Paul Enferm. 2011; 24(5):650-5.

24. Oliveira CGS, Beithum DF, Lima DT. O direito fundamental à saúde e o princípio da proteção integral da criança e do adolescente. Rev Direito Publico. 2011; 6(2):184-201.

25. Matumoto S, Vieira KCS, Pereira MJB, Santos CB, Fortuna CM, Mishima SM. Production of nursing care in primary health care services. Rev Latino-am Enfermagem. 2012; 20(4):710-7. 